\title{
Paideusis
}

\section{Autonomy in Teaching: A Response to Munro}

\section{Allen Pearson}

Volume 6, Number 2, 1993

URI: https://id.erudit.org/iderudit/1073307ar

DOI: https://doi.org/10.7202/1073307ar

See table of contents

Publisher(s)

Canadian Philosophy of Education Society

ISSN

0838-4517 (print)

1916-0348 (digital)

Explore this journal

Cite this article

Pearson, A. (1993). Autonomy in Teaching: A Response to Munro. Paideusis, 6(2), 33-35. https://doi.org/10.7202/1073307ar

(C) Allen Pearson, 1993

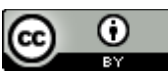

This document is protected by copyright law. Use of the services of Erudit (including reproduction) is subject to its terms and conditions, which can be viewed online.

https://apropos.erudit.org/en/users/policy-on-use/
This article is disseminated and preserved by Érudit.

Érudit is a non-profit inter-university consortium of the Université de Montréal, Université Laval, and the Université du Québec à Montréal. Its mission is to promote and disseminate research.

https://www.erudit.org/en/ 


\section{Autonomy in Teaching A Response to Munro}

\section{Allen Pearson, University of Alberta}

It is not unusual for philosophers of education, when looking at teaching, to give a general characterization or definition of teaching that would cover all its instances ${ }^{1}$ and, then, to discuss teaching as though it only takes place in formal classrooms with professional teachers in charge of twenty to thirty students. Munro adds to our understanding of teaching by considering teaching in a different but very common context, that of a teacher working with an individual student-in particular, the private music lesson. I think it would be possible to extend her discussion to a variety of other contexts in which there is a one-to-one student-teacher ratio. Much of what she says is, I feel, directly applicable in a context close to many of us, that of graduate education. How a graduate student learns philosophy of education is much more similar to how a student learns to play a musical instrument than to how a student learns grade eleven social studies. The phenomenon of learning from a master craftsperson, whether he or she be a flautist or a philosopher, is deserving of our careful attention, for it is a phenomenon of teaching that is important, interesting, and unstudied. Indeed, it may be desireable to start this venture in the context of musical education because there the aesthetic categories come to our attention immediately. This suggests that such categories may be important in other forms of master-student teaching. Indeed, it does seem important that the advanced-level student of philosophy, for example, come to see her discipline as one of wonder and beauty. So, there may well be many parallels here which will lead to provocative and insightful discussions.

Munro's argument is straightforward. She first describes for us the traditional music lesson. She states that such lessons are very unlike the kind of teaching we find in schools. She asks whether the traditional music lesson can promote some central educational values: autonomy, creativity, and selfrealization. She argues that it can; the bulk of her argument is concerned with autonomy. This is as it should be; once it can be established that the traditional music lesson can bring about autonomy, the other values follow easily. Creativity and self-realization presuppose autonomy, so Munro is right to put the weight of her argument here. In my discussion, I want to raise some questions rather than to disagree or develop a counter-position. Following Munro, the weight of my discussion will be on the question of the production of autonomous persons through the private music lesson.

The focus of Munro's discussion of autonomy is on how the music teacher teaches the student to think independently. But throughout the discussion, there are references to the "right" interpretation, to the fact that there can be several "right" interpretations, and that an interpretation need not necessarily be wrong. To talk in this way is to presuppose that there is a substantive distinction to be made between right and wrong interpretations in music. To say that there can be more than one right interpretation requires that it is possible that there is a wrong interpretation. If there were no such category, it would be meaningless to talk of a "right interpretation." The discussion of this section assumes that some interpretations are better than others. 
It is no doubt unreasonable to ask Munro to give us a full account of the criteria for interpretation in music. It is surely no simple matter and it is not her topic. But it is an issue that matters to the argument of this paper. If autonomy or independence of thought is to be striven for in private music teaching, without any concern for correctness of interpretation, then the private music lesson is essentially anarchic. A music teacher who strives to enable students to produce original, or at least independent, interpretations but who is not willing to say, "Wrong," "That doesn't work," "That interpretation is inappropriate," is a music teacher who does not care about the kind of music the student produces. Such a teacher would let anything go, so long as it is the independent creation of the student. But this is of course a caricature of what a music teacher does. The music teacher works hard to try to make the student's interpretation both autonomous and right. To do this, the music teacher must bave some criteria or conception of what is a correct interpretation. Munro helps us to understand how an autonomous interpretation comes about: she does not address the issue of a correct interpretation.

It does not seem that Schon's account is able to help us on this matter. "Framing reality" and having a stock of exemplars to bring to bear on a problematic situation do not seem to be sufficient for problem-solving. A problem is solved not when a person proposes a solution to a problem but when the proposed solution is a correct solution. We do not solve a problem unless the proposed solution works, no matter how autonomous or creative the proposal is. Schon has at best provided an account of how proposed solutions are derived; there seems to be nothing in his procedure that tells us if the proposed solutions are correct. So his account of interpretation in music can at best provide the basis for judging if a solution is autonomous or independent; it will not tell us if it is right.

Another issue concerns the relation Munro posits between the traditional music lesson and the educational goals of autonomy, creativity, and selfrealization. Munro argues that the traditional music lesson can be sufficient for autonomy, creativity, and self-realization. Is the traditional music lesson necessary for these educational goals?

Traditional schools, the authoritarian and inflexible institutions that seem to parallel Munro's music lesson, were able to produce autonomous, creative individuals. Too many creative, self-realized people came out of such schools for us to argue otherwise. But many want to claim that traditional schools are not necessary for the production of these educational goods. The problems identified with traditional schools are varied and, in light of those problems, some have tried to develop alternative forms of education that can produce the educational goods of autonomy, creativity, and self-realization. Similarly, one can ask if there are other ways of teaching music, besides the traditional music lesson, that produce autonomy, creativity, and self-realization. A progressive revolution in the music lesson might find ways of teaching music that do not rely on competition and its potentially harmful consequences such as Munro describes in her closing paragraphs.

It is exciting and refreshing to think of teaching in such a different context. In raising her questions, initiating the discussion, and offering her answers, Munro might well be suggesting that music teaching could use its Dewey, or perhaps, its Peters. 


\section{Notes}

${ }^{1}$ For an example as good as any and better than most, see Gary Fenstermacher, "Philosophy of Research on Teaching: Three Aspects," in M.C. Wittrock (ed.), Handbook of Research on Teaching, 3rd edition (New York: Macmillan, 1986), 38. 